\title{
Comparative study of the floral biology and of the response of productivity to insect visitation in two rapeseed cultivars (Brassica napus L.) in Rio Grande do Sul
}

\author{
Blochtein, B. ${ }^{a *}$, Nunes-Silva, P. ${ }^{a}$, Halinski, R. ${ }^{a}$, Lopes, LA. ${ }^{b}$ and Witter, S. ${ }^{c}$ \\ aLaboratório de Entomologia, Programa de Pós-Graduação em Zoologia, Departamento de Biodiversidade e Ecologia, \\ Faculdade de Biociências, Pontifícia Universidade Católica do Rio Grande do Sul - PUCRS, \\ Avenida Ipiranga, 6681, CEP 90619-900, Porto Alegre, RS, Brazil \\ ${ }^{\text {b} G r u p o ~ d e ~ p e s q u i s a ~ E d u c a c ̧ a ̃ o ~ e m ~ C i e ̂ n c i a s ~ e ~ M a t e m a ́ t i c a ~ p a r a ~ o ~ D e s e n v o l v i m e n t o ~ S u s t e n t a ́ v e l, ~ P r o g r a m a ~ d e ~ P o ́ s ~}$ \\ Graduação em Ensino de Ciências e Matemática, Universidade Luterana do Brasil - ULBRA, \\ Av. Farroupilha, 8001, CEP 92425-900, Canoas, RS, Brazil \\ 'Fundação Zoobotânica do Rio Grande do Sul, Museu de Ciências Naturais, Setor Manejo de Fauna, \\ Rua Dr. Salvador França, 1427, CEP 90690-000, Porto Alegre, RS, Brazil \\ *e-mail: betinabl@pucrs.br
}

Received: March 11, 2013 - Accepted: July 23, 2013 - Distributed: De mber 31, 2014

(With 6 figures)

\begin{abstract}
Planning the artificial pollination of agricultural crops requires knowledge of the floral biology and reproductive system of the crop in question. Many studies have shown that rapeseed (Brassica napus Linnaeus) is self-compatible and self-pollinated, but its productivity may be increased by insect visitation. In the present study, the floral biology and the response of productivity to insect visitation of two rapeseed cultivars (Hyola 420 and Hyola 61) were analyzed and compared in three regions of Rio Grande do Sul, Brazil. The rapeseed flowers presented three stages during anthesis, with the time periods varying between the cultivars. Both cultivars are self-compatible, but free visitation of insects increased productivity by $17 \%$ in the Hyola 420 cultivar and by approximately $30 \%$ in the Hyola 61 cultivar. Therefore, it is concluded that the cultivar Hyola 61 is more dependent on insect pollination than Hyola 420.
\end{abstract}

Keywords: floral biology, reproductive system, pollination, rapeseed, Brassica napus.

\section{Estudo comparativo da biologia floral e da resposta da produtividade à visita por insetos em duas cultivares de canola (Brassica napus L.) no Rio Grande do Sul}

\section{Resumo}

O planejamento de polinização dirigida nas culturas agrícolas requer o conhecimento da biologia floral e do sistema reprodutivo da cultura em questão. Muitos estudos mostram que a canola (Brassica napus Linnaeus) é auto compatível e auto polinizada, no entanto, sua produtividade pode ser aumentada pela visita por insetos. Nesse estudo, a biologia floral e a resposta da produtividade à visita por insetos de duas cultivares de canola (Hyola 420 e Hyola 61) foram analisadas e comparadas em três regiões do Rio Grande do Sul, Brasil. As flores de canola apresentaram três fases durante a antese, havendo variação no período de tempo de acordo com a cultivar. Ambas as cultivares são auto compatíveis, mas a livre visita por insetos aumentou a produtividade em 17\% na cultivar Hyola 420 e cerca de $30 \%$ na cultivar Hyola 61. Dessa maneira, concluímos que a cultivar Hyola 61 é mais dependente da polinização entomófila que a Hyola 420.

Palavras-chave: biologia floral, sistema reprodutivo, polinização, canola, Brassica napus.

\section{Introduction}

Pollination is an environmental service that contributes to both the maintenance of biodiversity and food production (Allen-Wardell et al., 1998). In nature, pollination is responsible for the reproduction of $87.5 \%$ of angiosperms (Ollerton et al., 2011), and in agriculture, it is estimated that $75 \%$ of crops require a degree of animal pollination
(Klein et al., 2007). The degree of pollination dependence, however, varies among crops. Whereas certain species, such as apples (Freitas, 1995) and passion fruit (Corbet and Willmer, 1980), are entirely dependent on pollinators for the production of fruits, other species, such as coffee (Roubik, 2002), tomato (Morandin et al. 2001a, b) and 
eggplant (Abak et al., 2000; Nunes-Silva et al., 2011), depend little on these agents. In such cases, even though visitation of pollinators is not essential, it is beneficial, as it increases production and improves the quality of fruits (Abak et al., 2000; Morandin et al. 2001a, b; NunesSilva et al., 2011).

Rapeseed (Brassica napus L., Brassicaceae) is an agricultural crop that benefits from animal pollination (Kevan and Eisikowitch, 1990; Adegas and Nogueira Couto, 1992; Durán et al., 2010; Rosa et al., 2010, 2011; Ali et al., 2011; Bommarco et al., 2012). It is the third most highly produced oleaginous plant worldwide (Tomm, 2005). In the south of Brazil, rapeseed is a component of grain production systems. Rapeseed stands out as an excellent economic alternative because, in addition to its use in crop rotations, where it shows positive effects on wheat, soybeans, beans and corn, the oil extracted from rapeseed seeds is consumed by people and is considered a functional food (Cunha, 2007). Rapeseed oil is also suitable for biodiesel production (Albuquerque, 2006).

Rapeseed flowers are considered to be self-pollinated. However, several studies have shown that insect pollination of these flowers increases the amounts of seeds produced (Kevan and Eisikowitch, 1990; Rosa et al., 2010; Ali et al., 2011), seed weight and quality (amount of oil) (Durán et al., 2010; Bommarco et al., 2012) and even the seed germination rate (Kevan and Eisikowitch, 1990), resulting in higher market values (Bommarco et al., 2012).

With the development of different plant cultivars for agriculture, many reproductive traits of a species may be modified. Such traits as dependency on pollination and the floral biology of different plant species, including rapeseed, can be affected during this process. Both of these traits are strongly related to productivity.

The study of floral biology may explain why certain pollinators are more efficient than others, given that it is essential that the pollinator visits flowers during the period in which the flower's stigmas are receptive. Defining a plant's reproductive system is also necessary to identify which floral visitors act as pollinators based on their visitation behavior. Thus, knowledge of both the floral biology and reproductive system of a plant is important for the development of efficient pollination management practices.

In the present study, the floral biology (1. flower morphophysiology; 2. analysis of anthesis; 3 . stigma receptivity; 4 . the viability of the pollen grains) and reproductive systems of the rapeseed (Brassica napus) cultivars Hyola 420 and Hyola 61 were characterized. The aims were: (a) to compare the floral biology of the two cultivars and verify if there are variations in floral biology among regions; (b) and to verify if there are differences in productivity between cultivars in response to insect pollination and region.

\section{Material and Methods}

\subsection{Study area}

The study was conducted on rapeseed plantations in three municipalities located in different ecoclimatic regions in Rio Grande do Sul:

Region 1 - Esmeralda, RS (2803'13" S and 51 ${ }^{\circ} 11^{\prime} 25^{\prime}$ 'W): belongs to the High Plateau region (região do Planalto Superior) of Serra do Nordeste and exhibits an altitude of $960 \mathrm{~m}$, relative humidity of 76 to $83 \%$, mean temperature of 14.4 to $16.8^{\circ} \mathrm{C}$, annual precipitation of 1,412 to $2,162 \mathrm{~mm}$ and a predominance of Araucaria fields and forest (IBDF, 1983; IBGE, 1992; Maluf and Caiaffo, 2001).

Region 2 - Estrela, RS, (29³0'07'S e 51 57'57'W): belongs to the Lower Hillside region (região da Encosta Inferior) of the Northeast region and is characterized by an altitude of $52 \mathrm{~m}$, relative humidity of $75 \%$, mean temperature of $19.3^{\circ} \mathrm{C}$, annual precipitation of $1,547 \mathrm{~mm}$ and a predominance of Subtropical forest (IBDF, 1983; IBGE, 1992; Maluff and Caiaffo, 2001).

Region 3 - Guarani das Missões, RS (latitude $28^{\circ}$ 08' 52" S and longitude 54 24' $10^{\circ}$ " W): belongs to the Missioneira Ecoclimatic region and shows temperatures between 18.8 and $19.6^{\circ}$, a relative humidity of 73 to $76 \%$ and an altitude of 175 to $425 \mathrm{~m}$. The predominant vegetation in this region is composed of fields, natural forest patches (capões) and Subtropical forest (Maluf and Caiaffo, 2001).

The cultivar planted at Esmeralda was Hyola 420, while Hyola 61 was planted at Estrela and Guarani das Missões.

\subsection{Floral biology of rapeseed flowers}

\section{a) Anthesis and stigma receptivity}

Floral development was studied in the pre-anthesis flower buds (minimum of five) of 10 plants. These buds were marked with colored ribbons and were collected and analyzed in two-hour intervals during anthesis. Anthesis is the period between flower opening and the onset of the senescence of the stamens and pistil (Faegri and Pijl, 1979). The stages of anthesis were characterized according to petal physiognomy, stamen position, dehiscence and pollen grain availability in the anthers, stigma receptivity and, with the aid of digital calipers, pistil height.

To assess stigma receptivity, stigmas were immersed with the aid of tweezers into a droplet of oxygen peroxide solution (3\%) on top of a histological slide. The formation of bubbles, indicating that the stigma is receptive (Dafni et al., 2005), was examined under a stereoscopic microscope.

b) Viability of pollen grains (germination rate)

The pollen germination rate was estimated following the methodology proposed by Bots and Mariani (2005). From the onset of anthesis, two anthers from each flower (from a minimum of three flowers) were collected and analyzed at pre-set time intervals (Esmeralda: 2, 4, 6 and 8 hours; Estrela: 12, 24, 36 and 48 hours; Guarani das Missões: 12, 24 and 36 hours). These anthers were placed into $100 \mu 1$ of preadipocyte growth medium (PGM: $0.01 \% \mathrm{H}_{3} \mathrm{BO}_{3}$, $0.07 \% \mathrm{CaCl}_{2} \mathrm{H}_{2}$ 0, 3.0\% PEG 6000 and $20 \%$ saccharose) for pollen germination and labeled regarding the sampling 
date, anthesis stage and growth time. After 2 or 4 hours of growth (five flowers in each treatment), the samples were fixed with formaldehyde $(0.87 \%)$.

Next, each sample was mounted on a histological slide, and 1,000 pollen grains were counted with the aid of a light microscope, recording the number of germinated and non-germinated pollen grains. The rate $(\%)$ of germinated pollen grains in each sample was then calculated for the different sampling times.

\subsection{Reproductive system}

In each treatment, pre-anthesis flower buds were covered with a fine-mesh fabric to preclude insects from accessing the flowers. The following treatments were included:

1) Autogamy: Flowers (Esmeralda: $n=18$; Estrela: $\mathrm{n}=46$; Guarani das Missões: $\mathrm{n}=18$ ) were covered individually during the entire anthesis period (excluding insects), and hand pollination was not conducted.

2) Xenogamy: Flowers (Esmeralda: $n=24$; Estrela: $\mathrm{n}=54$; Guarani das Missões: $\mathrm{n}=48$ ) were hand pollinated with pollen from another plant's flowers when the stigmas were receptive. Hand pollination was accomplished by transferring pollen grains between flowers with the aid of a fine-tipped brush.

3) Free visitation: Flowers were marked (Esmeralda: $\mathrm{n}=20$; Estrela: $\mathrm{n}=35$; Guarani das Missões: $\mathrm{n}=46$ ) but were not covered with fabric, allowing free visitor access.

The total number of siliques formed was assessed, and the silique formation rate (\%) was calculated for each treatment. The siliques were collected after they had completed development, and the number of seeds per silique as well as the total seed weight per silique were analyzed.

\subsection{Statistical analysis}

The analyzed variables are expressed as the mean values \pm standard deviation. Comparisons of pistil size between anthesis stages, the number and weight of seeds produced in the different treatments and regions and pollen germination rates at different times were performed by means of Kruskal-Wallis tests $(\alpha=0.05)$ with a posteriori multiple pairwise comparisons. The analyses were conducted using Statistica 7 and Sigma Plot 10.0 software.

\section{Results}

\subsection{Rapeseed floral biology}

Regardless of the examined variety, anthesis in the rapeseed flowers presented a three-stage sequence. However, variations were observed with regard to the durations of the flower phases and of the entire anthesis period.

The first stage involved partially open flower buds and occurred between two and three hours after the closed flower buds were marked. During this stage, the flowers were not yet receptive, and there was no nectar or pollen available. The majority of the anthers still faced the flower's interior, but some were found to be turned towards the petals and therefore faced the flower's exterior. In the second phase, the flowers were open and receptive and pollen and nectar were available. All of the anthers faced the flower's exterior with the exception of very few flowers that displayed anthers facing both the flower's interior and exterior. This stage began four to six hours after marking the closed flower buds. The duration of this stage was four to six hours for Hyola 420 and 12 to 23 hours for Hyola 61. In the third stage, even though the flowers were partially closed and exhibited signs of senescence, the stigma was still receptive. Nectar and pollen were no longer available. The flowers of the Hyola 420 cultivar displayed a shorter anthesis period $(12 \mathrm{~h})$ than those of the Hyola 61 cultivar ( $36 \mathrm{~h})$.

Significant differences were found in the flowers' pistil size between the different stages (Hyola 420: KruskalWallis test: $\mathrm{H}=35.0692, \mathrm{p}<0.001$; Hyola 61 : KruskalWallis test: $\mathrm{H}=19.5254, \mathrm{p}<0.001)$. The findings in this case showed that, as the flowers matured, the size of the pistil increased. For Hyola 420, the mean pistil size was $7.0 \pm 1.16 \mathrm{~cm}(\mathrm{n}=25)$ in stage $1,7.9 \pm 0.69 \mathrm{~cm}(\mathrm{n}=71)$ in stage 2 and $10.5 \pm 1.71 \mathrm{~cm}(\mathrm{n}=10)$ in stage 3 . For Hyola 61 , the mean pistil size was $7.4 \pm 2.6 \mathrm{~cm}(\mathrm{n}=10)$ in stage $1,8.0 \pm 0.48 \mathrm{~cm}(\mathrm{n}=10)$ in stage 2 and $10.1 \pm 0.34 \mathrm{~cm}$ $(\mathrm{n}=10)$ in stage 3 .

\subsection{Pollen grain viability (germination rate)}

At Esmeralda, the mean percentages of germinated pollen grains after 2, 4, 6 and 8 hours were $46.1 \% \pm 12.0 \%(n=6)$, $57.1 \% \pm 9.3 \%(\mathrm{n}=8), 61.8 \% \pm 6.8 \%(\mathrm{n}=3)$ and $64.8 \% \pm 8.4 \%$ $(n=5)$, respectively. There were no significant differences in the percentages of germinated pollen grains recorded at the different time points examined after anthesis (KruskalWallis test: $\mathrm{H}=2.5731, \mathrm{p}=0.4622$ ).

At Estrela, the mean percentages of germinated pollen grains after 12, 24 and 36 hours were $42.6 \% \pm 33.7 \%$ $(\mathrm{n}=7), 60.4 \% \pm 27.6 \%(\mathrm{n}=4)$ and $88.2 \% \pm 10.3 \%(\mathrm{n}=3)$, respectively. There were no significant differences in the percentages of germinated pollen grains observed at the different time points after anthesis (Kruskal-Wallis test: $\mathrm{H}=3.000, \mathrm{p}=0.2231$ ).

At Guarani das Missões, the mean percentages of germinated pollen grains after 12, 24 and 36 hours were $87.7 \% \pm 7.2 \%(\mathrm{n}=10), 92.9 \% \pm 5.2 \%(\mathrm{n}=10)$ and $95.0 \% \pm 1.3 \%$ $(\mathrm{n}=10)$, respectively. There was a significant difference detected in the percentages of germinated pollen grains (Kruskal-Wallis test: $\mathrm{H}=7.061, \mathrm{p}=0.0293$ ) at the different time points after anthesis, but only between 12 and 36 hours.

\subsection{Reproductive system}

\subsubsection{Comparison of production under different pollination treatments}

The percentage of flowers that formed siliques was highest in the free visitation treatment at Estrela and Esmeralda, while at Guarani das Missões, the treatment showing the highest percentage of silique formation was xenogamy (see Table 1). 
No significant differences were observed in Esmeralda regarding either the mean number of seeds per silique (Kruskal-Wallis test: $\mathrm{H}=1.44, \mathrm{p}=0.4872$ ) or seed weight (Kruskal-Wallis test: $\mathrm{H}=1.04, \mathrm{p}=0.5962$ ) between the three treatments (see Table 1). Despite the lack of significant differences, the mean number of seeds produced was greater under the xenogamy treatment, whereas seed weight was higher in the free visitation treatment (see Table 1).

At Estrela, there were no significant differences observed in the mean number of seeds per silique between the three treatments (Kruskal-Wallis test: $\mathrm{H}=2.33$, $\mathrm{p}=0.3114$; see Table 1); however, it was greatest in the autogamy treatment. In contrast, the total weight of seeds produced showed significant differences (Kruskal-Wallis test: $\mathrm{H}=9.53$, $\mathrm{p}=0.0085$; see Table 1) between the treatments, being higher for seeds resulting from autogamy.

For Guarani das Missões, there were significant differences found in both the mean number of seeds per silique (Kruskal-Wallis test: $\mathrm{H}=19.30, \mathrm{p}=0.0001$ ) and in seed weight (Kruskal-Wallis test: $\mathrm{H}=25.95, \mathrm{p}<0.001$ ) between the treatments (see Table 1), with both parameters exhibiting higher values in the free visitation and xenogamy treatments than under autogamy.

\subsubsection{Comparison of production between the different study sites and cultivars}

\subsubsection{Free visitation}

There were significant differences observed in the number of seeds per silique between all of the study sites (Kruskal-Wallis test: $\mathrm{H}=9.265, \mathrm{p}=0.0097$ ), except between Estrela and Guarani das Missões (see Figure 1). There were also significant differences in the weight of the seeds produced between the sites (Kruskal-Wallis test: $\mathrm{H}=25.115, \mathrm{p}<0.0001$ ), except between those produced at Esmeralda and in Guarani (see Figure 2).

\subsubsection{Xenogamy}

There were significant differences in the number of seeds per silique detected between the three study sites
(Kruskal-Wallis test: $\mathrm{H}=14.88, \mathrm{p}=0.0006$ ), with the exception of the Estrela versus Guarani das Missões comparison (see Figure 3). There were also significant differences in the weight of the seeds produced (Kruskal-Wallis test: $\mathrm{H}=23.17, \mathrm{p}<0.0001$ ), except between those produced at Esmeralda and in Guarani (see Figure 4).

\subsubsection{Autogamy}

Significant differences in the number of seeds per silique were identified between all of the study sites (Kruskal-Wallis test: $\mathrm{H}=10.23, \mathrm{p}=0.0060$ ), except between Estrela and

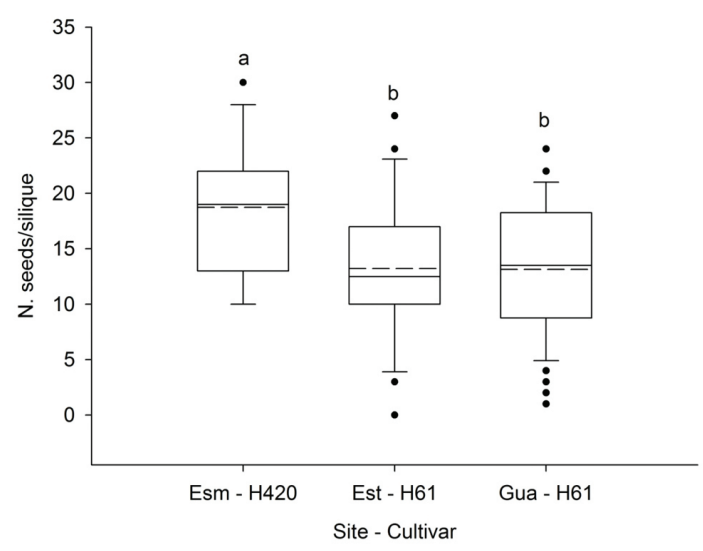

Figure 1. Number of seeds per silique in rapeseed (Brassica napus) produced under free visitation in the different study sites and cultivars, Esmeralda - Hyola 420 (Esm - H420), Estrela - Hyola 61 (Est - H61) and Guarani das Missões - Hyola 61 (Gua - H61). Different letters (a, b) indicate significant differences at $\mathrm{p}<0.05$ (Kruskal-Wallis test, $a$ posteriori multiple pairwise comparisons); Boxplot: the box represents the distribution of $50 \%$ of the values; the full horizontal line represents the median; the dashed horizontal line represents the mean; the whiskers represent the standard error (above $90 \%$ and below 10\%); and the filled circles represent outliers.

Table 1. Percentage of silique formation, mean number of seeds per silique and mean weight of the seeds produced from rapeseed (Brassica napus) flowers subjected to the different pollination treatments.

\begin{tabular}{|c|c|c|c|}
\hline & Esmeralda Hyola 420 & Estrela Hyola 61 & Guarani das Missões Hyola 61 \\
\hline & \multicolumn{3}{|c|}{$\%$ of silique formation } \\
\hline Free visitation & $95.0 \%(n=20)$ & $77.8 \%(n=35)$ & $91.3 \%(n=46)$ \\
\hline Xenogamy & $54.2 \%(n=24)$ & $63.0 \%(n=54)$ & $100 \%(n=48)$ \\
\hline \multirow[t]{2}{*}{ Autogamy } & $77.8 \%(n=18)$ & $45.7 \%(n=46)$ & $61.1 \%(n=18)$ \\
\hline & \multicolumn{3}{|c|}{ Number of seeds per silique (Mean $\pm \mathrm{SD})$} \\
\hline Free visitation & $19 \pm 6.2 \mathrm{~ns}(\mathrm{n}=19)$ & $13 \pm 6.5^{\mathrm{ns}}(\mathrm{n}=28)$ & $13 \pm 5.9^{\mathrm{a}}(\mathrm{n}=42)$ \\
\hline Xenogamy & $20 \pm 6.3 \mathrm{~ns}(\mathrm{n}=13)$ & $11 \pm 7.1^{\mathrm{ns}}(\mathrm{n}=34)$ & $14 \pm 6.5^{\mathrm{a}}(\mathrm{n}=48)$ \\
\hline \multirow[t]{2}{*}{ Autogamy } & $14 \pm 8.8 \mathrm{~ns}(\mathrm{n}=14)$ & $10 \pm 7.9^{\mathrm{ns}}(\mathrm{n}=21)$ & $4 \pm 3.2^{\mathrm{b}}(\mathrm{n}=11)$ \\
\hline & \multicolumn{3}{|c|}{ Seed weight $($ Mean \pm SD) } \\
\hline Free visitation & $0.103 \pm 0.038 \mathrm{~ns}(\mathrm{n}=19)$ & $0.036 \pm 0.040^{\mathrm{ab}}(\mathrm{n}=16)$ & $0.097 \pm 0.089^{\mathrm{a}}(\mathrm{n}=42)$ \\
\hline Xenogamy & $0.084 \pm 0.062 \mathrm{~ns}(\mathrm{n}=13)$ & $0.028 \pm 0.037^{\mathrm{a}}(\mathrm{n}=34)$ & $0.067 \pm 0.031^{\mathrm{a}}(\mathrm{n}=48)$ \\
\hline Autogamy & $0.087 \pm 0.054 \mathrm{~ns}(\mathrm{n}=14)$ & $0.054 \pm 0.033^{\mathrm{b}}(\mathrm{n}=18)$ & $0.016 \pm 0.015^{\mathrm{b}}(\mathrm{n}=11)$ \\
\hline
\end{tabular}

$\mathrm{N}=$ sample size; Different letters $(\mathrm{a}, \mathrm{b})$ indicate significant differences at $\mathrm{p}<0.05$ (Kruskal-Wallis test, a posteriori multiple pairwise comparisons); SD: standard deviation; ${ }^{\text {ns }}$ non-significant difference. 
Guarani das Missões and between Estrela and Esmeralda (see Figure 5). There were also significant differences in the weight of the seeds produced (Kruskal-Wallis test: $\mathrm{H}=11.83$, $\mathrm{p}=0.0027$ ), except between those produced at Estrela and the other two sites (see Figure 6).

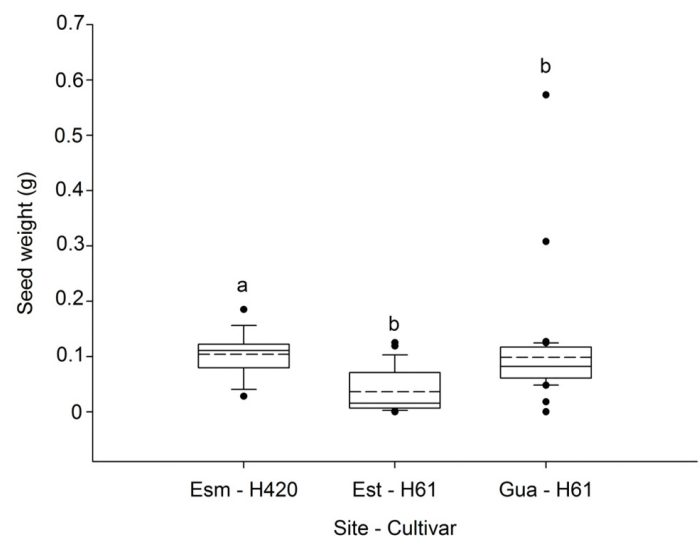

Figure 2. Weight of rapeseed (Brassica napus) seeds produced under free visitation in the different study sites and cultivars, Esmeralda - Hyola 420 (Esm - H420), Estrela - Hyola 61 (Est - H61) and Guarani das Missões - Hyola 61 (Gua - H61). Different letters (a, b) indicate significant differences at $\mathrm{p}<0.05$ (Kruskal-Wallis test, a posteriori multiple pairwise comparisons); Boxplot: the box represents the distribution of $50 \%$ of the values; the full horizontal line represents the median; the dashed horizontal line represents the mean; the whiskers represent the standard error (above $90 \%$ and below 10\%); and the filled circles represent outliers.

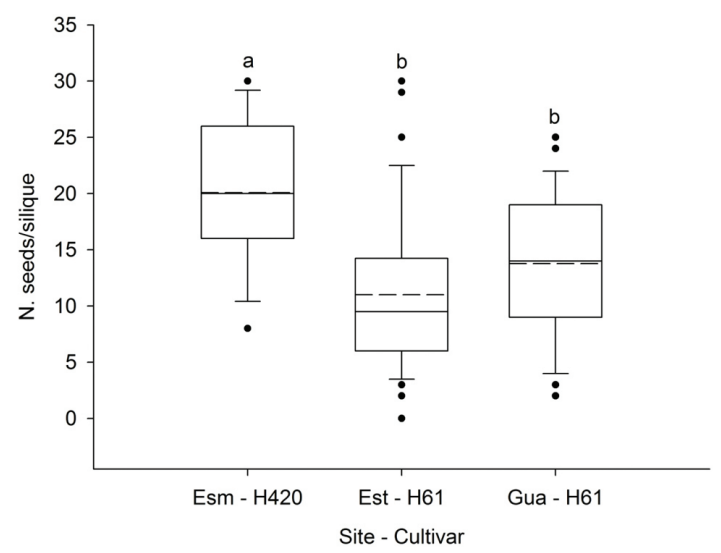

Figure 3. Number of seeds per silique in rapeseed (Brassica napus) produced under xenogamy in the different study sites and cultivars, Esmeralda - Hyola 420 (Esm - H420), Estrela - Hyola 61 (Est - H61) and Guarani das Missões - Hyola 61 (Gua - H61). Different letters (a, b) indicate significant differences at $\mathrm{p}<0.05$ (Kruskal-Wallis test, $a$ posteriori multiple pairwise comparisons); Boxplot: the box represents the distribution of $50 \%$ of the values; the full horizontal line represents the median; the dashed horizontal line represents the mean; the whiskers represent the standard error (above $90 \%$ and below 10\%); and the filled circles represent outliers.

\section{Discussion}

Floral biology can vary for different cultivars of a plant species. For example, different mango cultivars display different anthesis periods, and this characteristic

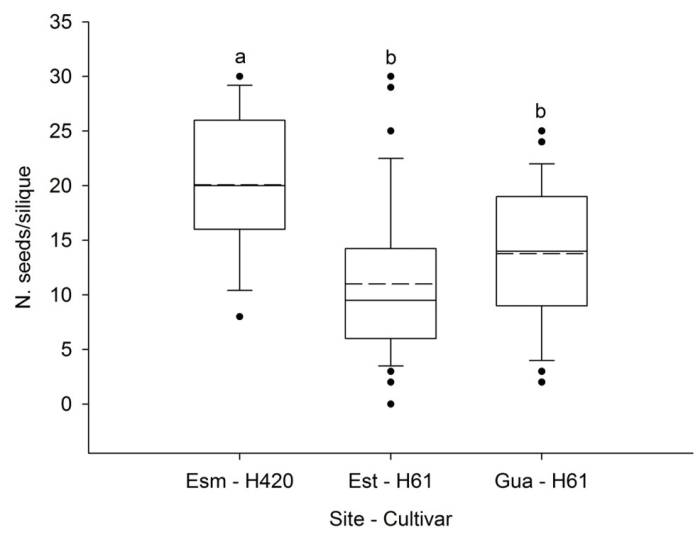

Figure 4. Weight of rapeseed (Brassica napus) seeds produced under xenogamy in the different study sites and cultivars, Esmeralda - Hyola 420 (Esm - H420), Estrela - Hyola 61 (Est - H61) and Guarani das Missões - Hyola 61 (Gua - H61). Different letters (a, b) indicate significant differences at $\mathrm{p}<0.05$ (Kruskal-Wallis test, a posteriori multiple pairwise comparisons); Boxplot: the box represents the distribution of $50 \%$ of the values; the full horizontal line represents the median; the dashed horizontal line represents the mean; the whiskers represent the standard error (above $90 \%$ and below 10\%); and the filled circles represent outliers.

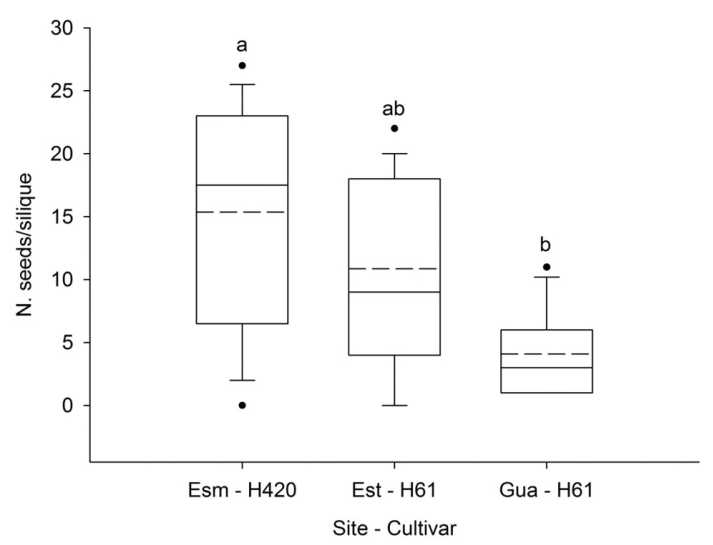

Figure 5. Number of seeds per silique in rapeseed (Brassica napus) produced under autogamy in the different study sites and cultivars, Esmeralda - Hyola 420 (Esm - H420), Estrela - Hyola 61 (Est - H61) and Guarani das Missões - Hyola 61 (Gua - H61). Different letters (a, b) indicate significant differences at $\mathrm{p}<0.05$ (Kruskal-Wallis test, $a$ posteriori multiple pairwise comparisons); Boxplot: the box represents the distribution of $50 \%$ of the values; the full horizontal line represents the median; the dashed horizontal line represents the mean; the whiskers represent the standard error (above $90 \%$ and below 10\%); and the filled circles represent outliers. 


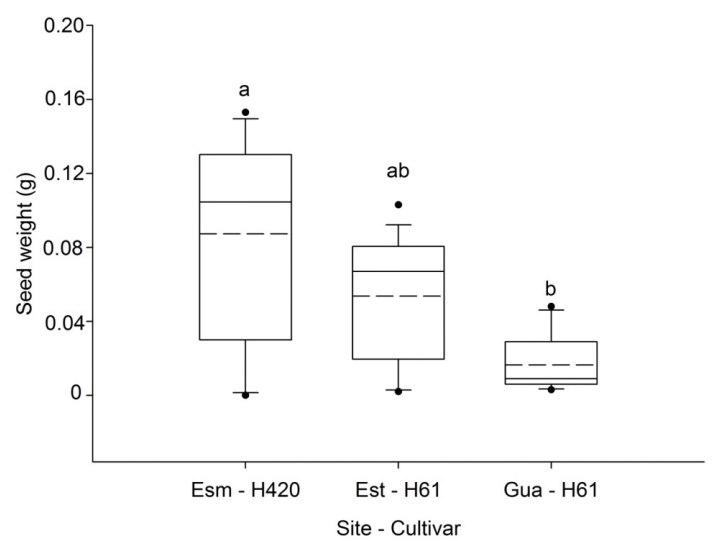

Figure 6. Weight of rapeseed (Brassica napus) seeds produced under autogamy in the different study sites and cultivars, Esmeralda - Hyola 420 (Esm - H420), Estrela - Hyola 61 (Est - H61) and Guarani das Missões - Hyola 61 (Gua - H61). Different letters (a, b) indicate significant differences at $\mathrm{p}<0.05$ (Kruskal-Wallis test, a posteriori multiple pairwise comparisons); Boxplot: the box represents the distribution of $50 \%$ of the values; the full horizontal line represents the median; the dashed horizontal line represents the mean; the whiskers represent the standard error (above $90 \%$ and below 10\%); and the filled circles represent outliers.

has been associated with the pollination type observed: a short-anthesis mango cultivar was shown to exhibit a higher rate of cross pollination, as the interval during which there is overlap in the opening of perfect and staminate flowers for this cultivar is short compared to other varieties (Pimentel et al., 1984). In the present study addressing rapeseed, differences in floral biology with respect to the anthesis period were also found between cultivars. At Estrela and Guarani das Missões, the flowers of the Hyola 61 cultivar exhibited a 36 -hour anthesis period, whereas at Esmeralda, the flowers of the Hyola 420 cultivar presented a 12-hour anthesis period. Other rapeseed cultivars have been reported to show different anthesis periods. For example, CTC-4 has been reported by different authors to exhibit an anthesis period of $32.5 \pm 8.6$ hours (Adegas and Nogueira Couto, 1992) or 48 hours (Mussury and Fernandes, 2000), and Hyola 432 shows an anthesis period of 72 hours (Rosa et al., 2010).

Despite the differences in the duration of anthesis between the Hyola 420 and Hyola 61 cultivars, both presented three stages of anthesis, with little variation observed between the cultivars and study sties. Additionally, both cultivars displayed pistil growth as the flowers matured, which resulted in growth of the stigma to the same size as the anthers, then surpassing them, as observed in other studies (Rosa et al., 2010).

In addition to pistil growth, torsion of the stamens was observed, positioning the dehiscent side of the anthers toward the flower's exterior, as reported in other studies on rapeseed (Mussury and Fernandes, 2000; Rosa et al., 2010). When the flowers were partially open, the anthers of the long stamens faced inward, though some flowers also displayed anthers facing outward. Rosa et al. reported that this torsion may favor cross pollination and limit autogamy, as the stigma is not receptive when the anthers are facing the flower's interior in the Hyola 432 cultivar (Rosa et al., 2010). However, the stigmas of the cultivars analyzed in the present study were receptive when there were still anthers facing inward, which enabled autogamy.

Another important factor for plant reproduction is the viability of pollen grains (Bots and Mariani, 2005). In the present work, the percentage of germinated pollen grains in the anthers tended to increase as the flowers matured (see Figures 1 to 3), being higher by the end of anthesis. This observation contrasts with the findings of Bots and Mariani (2005) and Rosa et al. (2010), who used the same method as in the present study but recorded a decrease in pollen viability as anthesis progressed. However, in apricots for example, it has been observed that there is variation in the percentage of germinated pollen grains between cultivars (Ruiz and Egea, 2008).

In addition to the floral biology of rapeseed, the reproductive system of this crop was also assessed. Rapeseed is self-compatible (Takahata, 2009), and silique formation was observed in the three treatments applied here (free visitation, xenogamy and autogamy; see Table 1), confirming that the Hyola 420 and Hyola 61 cultivars are also self-compatible. However, the free visitation and xenogamy treatments increased production compared to autogamy, as measured by the number of siliques formed (see Table 1); however, the xenogamy treatment at Esmeralda provided an exception to this pattern, as it resulted in a smaller percentage of siliques (see Table 1). Free visitation increased production by $17 \%$ in the Hyola 420 cultivar and by approximately $30 \%$ in the Hyola 61 cultivar. Similar results have been found by other researchers. For the Hyola 432 cultivar, a treatment allowing free visitation by insects (mainly $A$. mellifera) was found to increase the percentage of siliques formed by $22 \%$ compared to autogamy (Rosa et al., 2011).

Although the pollination treatments influenced silique production, the number of seeds per silique was not affected (see Table 1). Experiments in the CTC-4 cultivar showed similar results (Adegas and Nogueira Couto, 1992). However, at Guarani das Missões (Hyola 61 ), the free visitation and xenogamy treatments resulted in higher production of seeds per silique (see Table 1), as has previously been observed for the Hyola 432 cultivar, to which free visitation conditions were shown to increase the numbers of seeds present in the siliques (Rosa et al., 2011). Durán et al. (2010) also reported a greater number of seeds per silique when free insect visitation was allowed for flowers of the Artus cultivar.

Another important parameter in rapeseed production is seed weight. The weight of the seeds produced under free visitation was higher compared to those produced by autogamy and xenogamy in the Hyola 61 cultivar at Guarani das Missões (see Table 1); however, no differences were observed for the other study sites (see Table 1). 
Similar results have been observed in other studies (CTC4 cultivar: Adegas and Nogueira Couto, 1992; Hyola 432 cultivar: Rosa et al., 2011; SW Stratos ${ }^{\mathrm{TM}}$ cultivar: $^{2}$ Bommarco et al., 2012).

There was variation in the results obtained according to the regions where the experiments were conducted, and even though no significant differences were found for some parameters, there was a trend of an increased quantity and quality of seeds being produced under free visitation and xenogamy (see Table 1). When the two sites where the same cultivar (Hyola 61) was grown were compared, it was observed that seed weight was higher at Estrela under the autogamy treatment and at Guarani das Missões under the free visitation and xenogamy treatments. One hypothesis to explain this difference is that the amount of flower visitation is lower at Estrela than at Guarani das Missões, being insufficient to increase productivity and the quality of seeds to a level above the autogamy treatment, given that the pollinator density affects fruit production (Jauker et al., 2012). Another possible cause for this difference may be the composition of the pollinator community of each area, because the efficiency of pollinators varies with species (Ali et al., 2011).

Many authors have considered rapeseed to be selfpollinated, which means that its pollen may be transferred without the aid of pollinating agents. For example, Mussury and Fernandes (2000) observed that pollination may occur during pre-anthesis, as flowers already presented dehiscent anthers at this time. Several studies have shown that even without visitation by pollinators, there is formation of siliques and seeds (Adegas and Nogueira Couto, 1992; Bommarco et al., 2012); nevertheless, as mentioned above and also shown in the present study, production is increased when insect pollination occurs (Adegas and Nogueira Couto, 1992; Durán et al., 2010; Rosa et al., 2011; Bommarco et al., 2012; Jauker et al., 2012). However, the positive effects on seed production and quality may vary between cultivars and plantation sites, as differences in the number of seeds per silique and seed weight were found between the study sites (see Figures 1 to 6). Pavlista et al. (2011) also observed differences in silique productivity and quality between production regions. For the cultivars studied, it is concluded that the cultivar Hyola 61 is more dependent on insect pollination than Hyola 420.

\section{Acknowledgments}

The authors thank CNPq (Conselho Nacional de Desenvolvimento Científico e Tecnológico / National Counsel of Technological and Scientific Development) (Process 556635/2009-4) and GEF/FAO/FUNBIO (Global Environment Facility / Food and Agriculture Organization / Brazilian Biodiversity Fund [Fundo Brasileiro para a Biodiversidade]) for financial support. We also thank Annelise de Souza Rosa, Daniela Loose, Jenifer Ramos, Juliana Galaschi Teixeira, Mariana Zaniol Fernandes and Fernando Dias for the assistance provided during field work and the promoting companies Giovelli Cia Ltda,
Rota Agrícola, BSBIOS and the agriculture collective Cooperagri for providing support with the farmers.

\section{References}

ABAK, K., OZDOGAN, AO., DASGAN, HY., DERIN, K. and KAFTANOGLU, O., 2000. Effectiveness of bumble bees as pollinators for eggplants grown in unheated greenhouses. Acta Horticulturae, vol. 514, p. 197-203.

ADEGAS, JEB. and NOGUEIRA COUTO, RH., 1992. Entomophilous pollination in rape (Brassica napus L. var oleifera) in Brazil. Apidologie, vol. 23, no. 3, p. 203-209. http://dx.doi. org/10.1051/apido:19920302.

ALBUQUERQUE, GA., 2006. Avaliação reológica e caracterização fisico-química do biodiesel de canola e misturas. Available from: $<$ http://www.biodiesel.gov.br/docs/congressso2006/Armazenamento/ AvaliacaoReologica3.pdf>. Access in: 20 July 2008.

ALI, M., SAEED, S., SAJJAD, A. and WHITTINGTON, A., 2011. In search of the best pollinators for canola (Brassica napus L.) production in Pakistan. Applied Entomology and Zoology, vol. 46, no. 3, p. 353-361. http://dx.doi.org/10.1007/s13355-011-0051-0.

ALLEN-WARDELL, G., BERNHARDT, P., BITNER, R., BURQUEZ, A., BUCHMANN, S., CANE, J., COX, PA., DALTON, V., FEINSINGER, P., INGRAM, M., INOUYE, D., JONES, CE., KENNEDY, K., KEVAN, P., KOOPOWITZ, H., MEDELLIN, R., MEDELLIN-MORALES, S., NABHAN, GP., PAVLIK, B., TEPEDINO, V., TORCHIO, P. and WALKER, S., 1998. The potential consequences of pollinator declines on the conservation of biodiversity and stability of food crop yields. Conservation Biology, vol. 12, no. 1, p. 8-17.

BOMMARCO, R., MARINI, L. and VAISSIÈRE, BE., 2012. Insect pollination enhances seed yield, quality, and market value in oilseed rape. Oecologia, vol. 169, no. 4, p. 1025-1032. http:// dx.doi.org/10.1007/s00442-012-2271-6. PMid:22311256

BOTS, M. and MARIANI, M., 2005. Pollen viability in the field. Radboud Universiteit Nijmegen. Available from: $<$ www.cogem. net/ContentFiles/Pollen_viability.pdf $>$. Access in: 23 May 2008.

CORBET, SA. and WILLMER, PG., 1980. Pollination of the yellow passion fruit? Nectar, pollen and carpenter bees. The Journal of Agricultural Science, vol. 95, no. 03, p. 655-666. http://dx.doi.org/10.1017/S0021859600088055.

CUNHA, GR., 2007. Agroenergia: o futuro que chegou. Passo Fundo: O Nacional. 52 p.

DAFNI, A., KEVAN, PG. and HUSBAND, BC., 2005. Practical pollination biology. Canada: Enviroquest. 590 p.

DURÁN, XA., ULLOA, RB., CARRILLO, JA., CONTRERAS, JL. and BASTIDAS, MT., 2010. Evaluation of yield component traits of honeybee-pollinated (Apis mellifera L.) rapeseed canola (Brassica napus L.). Chilean Journal of Agricultural Research, vol. 70, no. 2, p. 309-314.

FAEGRI, K. and PIJL, VD., 1979. The principles of pollination ecology. Oxford: Pergamon Press. 244 p.

FREITAS, BM., 1995. The pollination efficiency of foraging bees on apple (Malus domestica Borkh) and cashew (Anacardium occidentale L.). Cardiff: University of Wales. 197 p. PhD Thesis on Bees and Pollination.

Instituto Brasileiro de Desenvolvimento Florestal - IBDF, 1983. Inventário Florestal Nacional: Florestas Nativas: Rio Grande do Sul. Brasília: Embrapa florestas. 345 p. 
Instituto Brasileiro de Geografia e Estatística - IBGE, 1992. Manual técnico da vegetação brasileira. Rio de Janeiro: Fundação IBGE. $92 \mathrm{p}$.

JAUKER, F., BONDARENKO, B., BECKER, HC. and STEFFAN-DEWENTER, I., 2012. Pollination efficiency of wild bees and hoverflies provided to oilseed rape. Agricultural and Forest Entomology, vol. 14, no. 1, p. 81-87. http://dx.doi. org/10.1111/j.1461-9563.2011.00541.x.

KEVAN, PG. and EISIKOWITCH, D., 1990. The effects of insect pollination on canola (Brassica napus L. cv. O.A.C. Triton) seed germination. Euphytica, vol. 45, p. 39-41.

KLEIN, AM., VAISSIÈRE, BE., CANE, JH., STEFFAN-DEWENTER, I., CUNNINGHAM, SA., KREMEN, C. and TSCHARNTKE, T., 2007. Importance of pollinators in changing landscapes for world crops. Proceedings. Biological Sciences, vol. 274, no. 1608, p. 303-313. http://dx.doi.org/10.1098/rspb.2006.3721. PMid:17164193

MALUF, JRT. and CAIAFFO, MRR., 2001. Regiões Ecoclimáticas do Estado do Rio Grande do Sul. In XII Congresso Brasileiro de Agrometeorologia and III Reunião Latino-Americana de Agrometeorologia, 2001. Fortaleza. Fortaleza: Sociedade Brasileira e Agrometeorologia. p. 151.

MORANDIN, LA., LAVERTY, TM. and KEVAN, PG., 2001a. Bumble bee (Hymenoptera: Apidae) activity and pollination levels in commercial tomato greenhouses. Journal of Economic Entomology, vol. 94, no. 2, p. 462-467. http://dx.doi.org/10.1603/0022-049394.2.462. PMid:11332840

MORANDIN, LA., LAVERTY, TM. and KEVAN, PG., 2001b. Effect of bumble bee (Hymenoptera: Apidae) pollination intensity on the quality of greenhouse tomatoes. Journal of Economic Entomology, vol. 94, no. 1, p. 172-179. http://dx.doi. org/10.1603/0022-0493-94.1.172. PMid:11233110

MUSSURY, RM. and FERNANDES, W., 2000. Studies of the Floral Biolgy and Reproductive System of Brassica napus L. (Cruciferae). Brazilian Archives of Biololgy and Technology, vol. 43 , no. 1, p. 111-117.

NUNES-SILVA, P., SILVA, CI., ROLDAO, Y., HRNCIR, M. and IMPERATRIZ-FONSECA, VL., 2011. The behavior of the stingless bee Melipona fasciculata (Apidae, Meliponini) on eggplant flowers and consequences for pollination. In 42nd
International Apicultural Congress (Apimondia), 2011. Buenos Aires. Buenos Aires: Apimondia. p. 208

OLLERTON, J., WINFREE, R. and TARRANT, S., 2011. How many flowering plants are pollinated by animals? Oikos, vol. 120, no. 3, p. 321-326. http://dx.doi.org/10.1111/j.1600-0706.2010.18644.x.

PAVLISTA, AD., SANTRA, DK., ISBELL, TA., BALTENSPERGER, DD., HERGERT, GW., KRALL, J., MESBACH, A., JOHNSON, J., O'NEIL, M., AIKEN, R. and BERRADA, A., 2011. Adaptability of irrigated spring canola oil production to the US High Plains. Industrial Crops and Products, vol. 33, no. 1, p. 165-169. http:// dx.doi.org/10.1016/j.indcrop.2010.10.005

PIMENTEL, RB., CORONEL, RE. and ESPINO, RRE., 1984. Floral biology and fruit set in mango (Mangifera indica L.) cultivars: "Carabao", "Pico" and Kancha Mitha. Philippine Journal of Crop Science, vol. 9, no. 1, p. 47-51.

ROSA, AS., BLOCHTEIN, B., FERREIRA, NR. and WITTER, S., 2010. Apis mellifera (Hymenoptera: Apidae) as a potential Brassica napus pollinator (cv. Hyola 432) (Brassicaceae), in Southern Brazil. Brazilian Journal of Biology $=$ Revista Brasileira de Biologia, vol. 70, no. 4, p. 1075-1081. http://dx.doi.org/10.1590/ S1519-69842010000500024. PMid:21180917

ROSA, AS., BLOCHTEIN, B. and LIMA, DK., 2011. Honey bee contribution to canola pollination in Southern Brazil. Scientia Agricola, vol. 68, no. 2, p. 255-259. http://dx.doi.org/10.1590/ S0103-90162011000200018.

ROUBIK, DW., 2002. The value of bees to the coffee harvest. Nature, vol. 417, no. 6890, p. 708. PMid:12066176

RUIZ, D. and EGEA, J., 2008. Analysis of the variability and correlations of floral biology factors affecting fruit set in apricot in a Mediterranean climate. Scientia Horticulturae, vol. 115, no. 2, p. 154-163. http://dx.doi.org/10.1016/j.scienta.2007.08.016.

TAKAHATA, Y., 2009. Floral variation in the subtribe Brassicinae with special reference to pollination strategies and pollen-ovule ratios. In GUPTA, SK. Biology and Breeding of Crucifers. London: Taylor \& Francis Group, LLC. p. 69-78. http://dx.doi. org/10.1201/9781420086096.ch4.

TOMM, GO., 2005. Situação em 2005 e perspectivas da cultura de canola no Brasil e em países vizinhos. Boletim de Pesquisa e Desenvolvimento online. Available from: $<$ http://www.cnpt. embrapa.br/biblio/bp/p_bp26.htm>. Access in: 17 March 2008. 